- Dumping Deadline

-.. Projects, Policies and Environmental Impact Assessment: A Look Inside California's Black Box (G. Wandesforde-Smith)

Federal Republic of Germany

- Plant Emissions to be Analyzed

United Kingdom

- Proposed EEC Directives: Member States Balk (S. Nagel)

- Energy Conservation: How far should the law intervene? (J. C. Woodliffe)

\section{EUROPEAN COMMUNITIES}

The legal Basis for Environmental Policy (K. v. Moltke)

Treaty Amendment

Bird Protection

Polluter Pays

Environmental Cooperation with Switzerland

Incompatibility of the 16 th Amendment to the Italian Law on Hunting with the Commission's Proposal for a Directive on Bird Conservation

Treaty on Land-Based Mediterranean Pollution

EEC Admits Toxic Substances Regulations are Inadequate

Petition to Hault Erosion

\section{INTERVIEWS}

Norway's Environment Minister: Dr. Gro Harlem Brundtland Cecil Andrus: US Secretary of the Interior (W. E. Burhenne)

Mr. Russell Train (Former Administrator of the Environmental Protection Agency

Speech of Sir Peter Scott on being presented with the International Pahlavi Environment Prize for 1977

\section{NON GOVERNMENTAL ORGANIZATIONS}

Loudon New WWF President

UICN: Bilan Positif (A.-Ch. Kiss)

Strong to IUCN

\section{COURT CASES}

Transfrontier Pollution: Plaintiff can choose his court

\section{BOOK NOTES}

International Environment Programmes: A Guide to the Subject Matter

\section{SELECTED DOCUMENTS}

La Conférence Interparlementaire sur la Pollution du Rhin (Interparliamentary Conference on Rhine Pollution)

First International Symposium: Gray Whale

International Conference of Appellate Magistrates

La Pollution Maritime Provenant des Plates-formes de Forage en Mer (Sea Pollution Caused by Oil-drilling Platforms)

UNP Governing Council

Convention on Civil Liability for Oil Spills Committee on Environment

Revised Draft Convention on the Conservation of Migratory Species of Wild Animals

Explanatory Notes on Revised Draft Convention on the Conservation of Migratory Species of Wild Animals

Excerpt from Positive Economic Aspects of Environmental Protection - Research report of the Federal Ministry of the Interior (Germany) by Prof. W. Meissner and Prof. Erich Hödl 194

Resolution of the Executive Committee of the European Environmental Bureau on "the Fast Breeder Option in the Community Context"

Text of Tbilisi Declaration

Extracts from the Proposed New USSR Constitution on the Provision of Water and the Control of the Disposal of Wastes as Prerequisites to the Development of the Human Environment

European Industry and its Environment: The Fundamental Principles

'Industrie Européenne et son Environnement: Les Principes Fondamentaux \title{
(1)
}

\section{Author Index of Volume 3}

Bakacs, Tibor, 20

Becker, S. William, 79

Birr, M., 71

Brady, Gordon L., 158

Brundtland, Gro Harlem, 40

Burhenne, Wolfgang E., 86, 126

Burkhardt, D., 71

Cano, Guillermo J., 66

Compton, Ruby I., 129

Connelly, Robert, 6

Des Clers, Bertrand, 155

Despax, Michel, 147

Dolzer, Rudolf, 120

Downing, Paul B., 158

Ducret, Clause, 6

Fleischer, Carl August, 3, 76, 100
Gibbons, Suedeen M., 129

Gour-Tanguay, Raymonde, 2, 8, 61

Hashimoto, H., 144

Heffernan, Patrick, 17

Heijnsbergen, P. van, 85

Kiss, A.-Ch., 16, 20, 74, 78, 151

Magarinos de Mello, Mateo J., 132

McCloskey, Maxine, 114

Mitchell, Heather, 50

Moltke, Konrad von, 22, 136

Moshofsky, William J., 37

Nagel, Stephan, 125, 175

Navid, Daniel B., 13

Pinto, Christopher W., 11
Prieur, Michel, 151

Remond-Gouilloud, M., 126

Rest, Alfred, 41

Sandbach, Francis, 32

Singh, Nagendra, 24

Sohn, Louis B., 98

Stoel, Thomas B., Jr., 129

Tamir, Josef, 75

Vosburgh, J. A., 34

Vosburgh, Ly-Beth, 34

Wandesforde-Smith, Geoffrey, 167

Willheim, Ernst, 109

Woodliffe, J. C., 177

Environmental Policy and Law, 3 (1977) 